\title{
Környezet és kémia: határterületek és határfelületek
}

\author{
DÉKÁNY Imre* \\ Szegedi Tudományegyetem, Fizikai Kémiai és Anyagtudományi Tanszék, 6720 Szeged, Aradi v.t.1., Magyarország
}

\section{Bevezetés}

Természetes környezetünket vizsgálva feltűnik számunkra, hogy a különböző felületek találkozására (szilárd/folyadék/ gáz) számtalan példát találhatunk ${ }^{1,2}$. Így első közelítésben vizsgáljuk meg egy folyó partját, ahol a mederben lévő víz számos oldott anyagot tartalmaz amely érintkezik a meder szilárd anyagával, ahol a legkülönbözőbb ásványféleségek fordulnak elő. De ez a szilárd talajfelszín találkozik a levegővel, ahol a megfelelő és az adott kontinens sajátságaira jellemző növényzet található és tekintettel a folyómederben lévő természetes vízre, a víz környezetében magas páratartalommal jelen vannak a levegő gázfázisában azok a folyadék cseppek, amelyekben számos oldott anyag, különböző molekulák fordulhatnak elő (1. ábra).

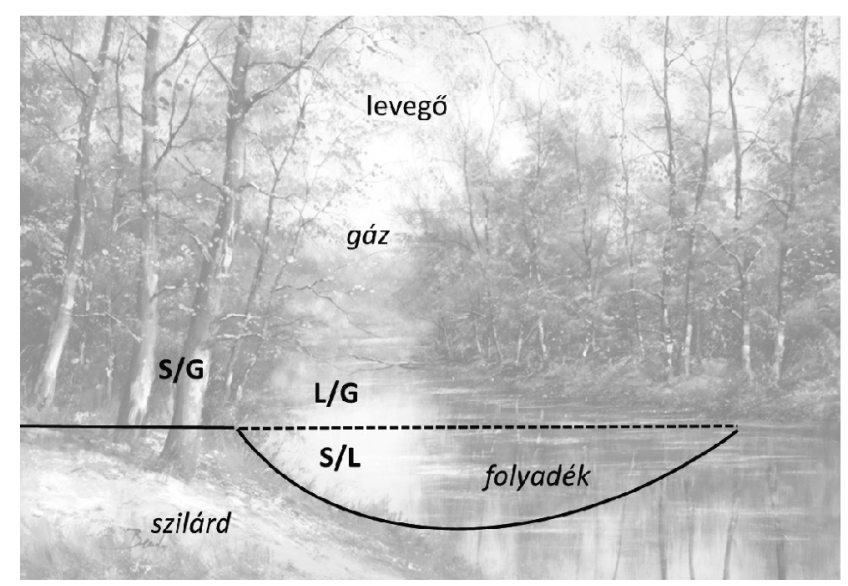

1. ábra. A határfelületek megjeleníthetők Benda Zoltán: „Folyóparti nyugalom" címü festményén.

A folyadék elpárolgása következtében természetesen kialakulnak nagyobb légköri magasságokban a megfelelö felhők, amelyekből visszakapjuk a csapadékot egy kondenzációs folyamat során. Ezen felhők szerkezete a gázban/levegőben szétoszlatott vízcseppeket jelentik, amelyeket aeroszoloknak is nevezhetünk. Ugyanakkor számolni kell azzal, hogy a folyómederben lévő víz találkozik az esetlegesen odakerülő szerves folyadékokkal, növényi olajokkal, esetleg szénhidrogén származékokkal, amelyek bejuthatnak a talaj pórusos szerkezetébe és onnan beszivároghatnak a folyómederben lévő vízbe. Ebben az esetben viszont folyadék-folyadék határfelület kialakulásával kell számolni, ami egyenletesen eloszlatott szerves folyadékcseppeket jelent a vizes fázisban. Abban az esetben, ha a környezet pl. mosószerekkel szennyeződik, vagy a mosószerek diffundálnak a talaj kapillárisaiba, akkor a szerves folyadék cseppek diszpergálódhatnak (szolubilizálódhatnak) a vizes fázisban és micellákat képeznek ${ }^{2}$. További szerves anyagmennyiségnek az élővízbe való bejutása az emulziók képződéséhez vezethetnek, amennyiben megfelelő mennyiségü mosószer (felületaktív anyag) áll rendelkezésünkre (2. ábra).

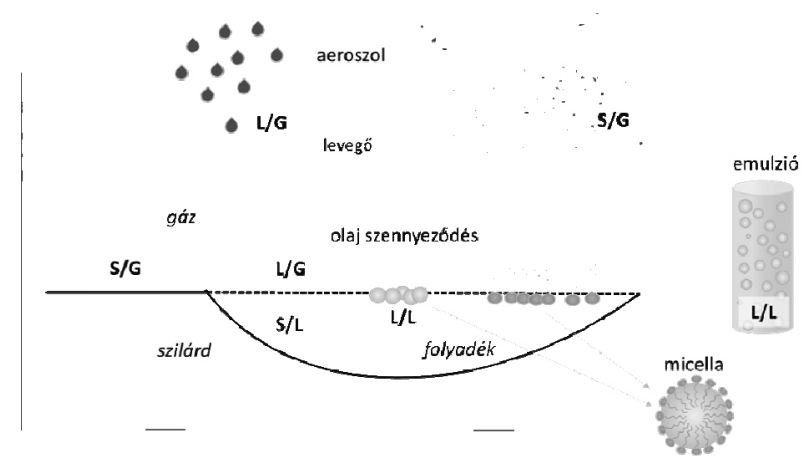

2. ábra. A különböző halmazállapotú anyagok határfelületi érintkezése új diszperz rendszerek keletkezését jeleni a környezetünkben.

A fentiek figyelembe vételével tehát meg van a lehetőségünk arra, hogy szisztematikusan vizsgálni tudjuk a környezetünkben keletkező diszperz rendszerek tulajdonságait a különböző fázisok találkozása folytán kialakuló határfelületek csoportosítása szerint ${ }^{2,3}$. A határfelületi rétegek képződése a fázisok közötti molekuláris kölcsönhatások eredménye, amely erők a határrétegben - az erőtér inhomogén és anizotróp jellege miatt- a molekulák feldúsulását jelenti. A képződött adszorpciós réteg (határfelületi fázis) jellemzése a határfelületi termodinamikai potenciál függvényekkel kvantitatíve megadható. Itt meg kell jegyezni azt, hogy a rétegek molekuláris rendezettségét és szerkezetét a belső fázis tulajdonságai (pld. koncentrációja, kémiai potenciálja) határozzák $\mathrm{meg}^{3}$. Ez a technológia számára azt jelenti, hogy a képződött diszperz rendszerek kinetikai álladóságát a belső (tömbi) fázis tulajdonságainak célszerü megválasztásával szabályozhatjuk.

\section{Folyadék-gáz és szilárd-gáz határfelületek}

Amennyiben a levegőben - mint gázfázisban folyadékcseppeket diszpergálunk vagy kondenzációs folyamatok során a telített vízgőzből folyadékcseppek keletkeznek, aeroszolokhoz jutunk. Természetesen a rendszert tovább bonyolítja az, hogy a levegőben lévő porszemcsék amelyek a nanométeres tartománytól akár a több száz mikrométeres tartományig terjednek - a levegő áramlásának

\footnotetext{
* e-mail: i.dekany@chem.u-szeged.hu
} 
következtében újabb határfelület típus alakul ki, ez pedig a szilárd-gáz határfelület. Ennek következtében azzal is számolni kell, hogy úgy a szilárd porszemcsék felületén, mint a talajt alkotó komponensek (szilikátok, agyagásványok stb.) felületén adszorpciós folyamatokkal kell számolni, amelyeket a határfelületi fizikai kémiában megadott összefüggések ismeretében kvantitatív módon írhatunk le és ezen összefüggések ismeretében elöre ki tudjuk számítani azokat az anyagmennyiségeket, amelyeket a szilárd anyag megköt és ezek a megkötött anyagok a környezetre káros anyagok is lehetnek. Ebből a szempontból tehát fontos annak ismerete, hogy elöre meghatározzuk a környezetvédelmi technológiákban azokat a technológiai paramétereket, amelyek ismeretében akár az aeroszolok megkötése, a levegő tisztítása és a talajok kármentesítése megtörténhet.

A folyómederbe érve közvetlen példát látunk a szilárd-folyadék határfelületek megjelenésére, ahol pl. a vizes fázisban lévő oldott anyagok a folyómedret alkotó pórusos szerkezetü talajkomponensekkel érintkeznek. A szilárd-folyadék határfelületi adszorpció ismerete tehát fontos a talajban, ill. a folyadékmederben megkötött anyagmennyiségek meghatározása vonatkozásában, vagyis ebben az esetben is az adszorpciós izotermák ismeretében számításokat végezhetünk a környezetvédelmi technológiák pontosításához. Mivel első közelítésben vizes közegből történő adszorpció a legfontosabb számunkra, lényeges, hogy az oldatban lévő különböző elektrolit komponensek (nátrium-, kálcium-, magnézium sók) milyen módon kötődhetnek a szilárd-folyadék határfelületen. Talán a legfontosabbak az egyszerü fizikai adszorpciós folyamatok mellett az ioncsere folyamatok. Ennek következtében pl. jelentős mennyiségü környezetre káros nehézfém ionok kötődnek meg a talajokban, ill. a folyómederben. Abban az esetben, ha a folyóba mosószerek, gyógyszermolekulák kerülnek, ezek adszorpciójával is számolni kell, amelyek veszélyeztetik a környezetünket, tekintettel arra, hogy az adszorpciós folyamatok során jelentős mennyiségü káros anyag dúsulhat fel a szilárd adszorbens felületi rétegében.

\subsection{Folyadék-folyadék határfelület}

A vizes fázis érintkezhet vízzel nem elegyedő szerves folyadékokkal (szénhidrogének, növényi olajok, zsírok), amelyek ugyan nem tudnak elegyedni a jelentős polaritás különbség miatt a vizes fázissal, de tekintettel arra, hogy szennyező anyagként a környezetbe kerülő mosószerek jelen vannak, a kolloidkémiában jól ismert emulzióképződési folyamatok jöhetnek létre, amelyek következtében folyadék-folyadék határfelületi emulziós rendszerek keletkeznek. Ezen folyamatoknak jelentősége a környezetvédelem mellett a kőolaj kitermelésben van, tekintettel arra, hogy a kőolaj fontos energiahordozó és vegyipari alapanyag is. Az olajos fázis folyadékba juttatása során - amely nagyon veszélyes a környezetre - ún. szolubilizációs folyamatokban a szerves molekulák a tenzid micellákba záródhatnak be. Ezek mérete néhány nanométertől néhány száz nanométerig terjedhet. A veszély abban rejlik, hogy ezek a részecskék már mikroszkóp alatt sem láthatók, jelenlétük csak fényszórásmérésekkel igazolható. Vagyis a szolubilizációs folyamatban a mindennapi életvitelben nem észlelhető ,vizes fázisban való oldódás" történik, amely számos veszélyes anyag élővízbe, ill. ivóvízbe való bevitelét jelentheti. Tekintettel ezen szerves szennyezők igen alacsony koncentrációjára (néhány ppm) csak precíz analitikai módszerek birtokában lehetséges ezek kimutatása (3. ábra).
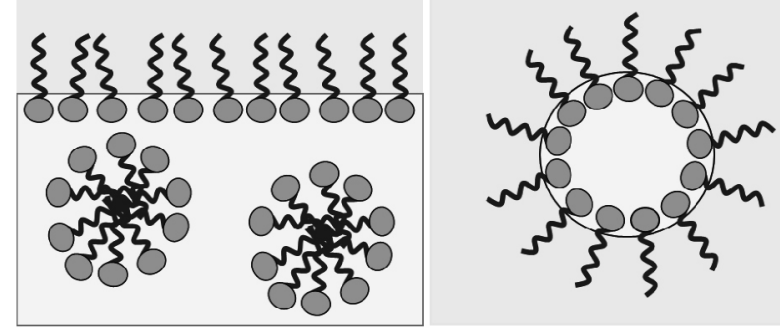

3. ábra. A tenzidek és gömbmicellák vizes és szerves közegben.

\section{A környezetvédelmi technológiák alkalmazása a szennyezések eltávolítása céljából}

A környezetvédelmi technológiák irodalma rendkívül szerteágazó és az elmúlt évszázadban számos technológiát dolgoztak ki a vegyészek és a mérnökök, tekintettel arra, hogy a környezet tisztasága alapvető számunkra. Ezért a hagyományos környezet tisztítási eljárásokkal ezen bevezetőben nem tudunk foglalkozni, csupán a szilárd-folyadék ill. a szilárd-gáz határfelületen alkalmazható tisztítási technológiák vonatkozásában szeretnénk bemutatni a fotokatalitikus tisztítás elvét, amely lényegében a határfelületi fizikai-kémia egyik alkalmazási lehetősége a napenergia felhasználásával a környezetvédelmi technológiában ${ }^{4,5}$.

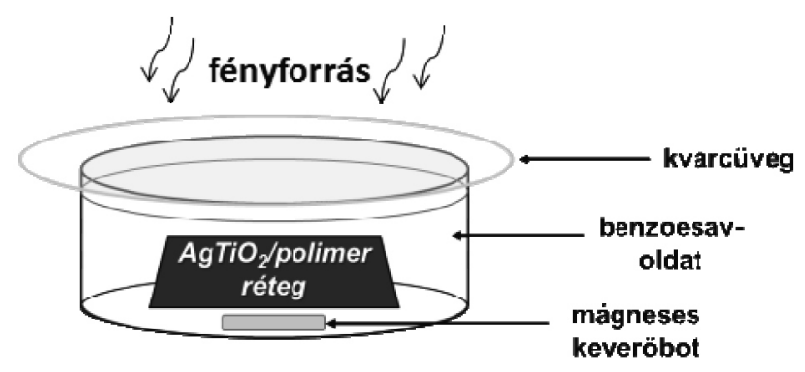

4. ábra. A fotokatalítikus bontáshoz alkalmazott kísérleti berendezés.

Ezen folyamatok közül a 4. ábrán bemutatott fotoreaktor müködtetésével javasolunk levegő ill. folyadék tisztítási technológiákat. A fotokatalitikus müködtetés lényege abban áll, hogy a szilárd-gáz határfelületen ill. a szilárd-folyadék határfelületen a napfény energiájával müködtetünk olyan fotokatalizátorokat, amelyek felületén az adszorpciós rétegükben megkötött szennyezés oxidálódik és pl. a szerves molekulák teljes mineralizálódása végbe megy, amely szénhidrogén vegyületek esetében a szén-dioxid végtermék keletkezését jelenti ${ }^{6-8}$. Az 5. ábrán példát láthatunk egy nanoezüst részecskékkel módosított titán-dioxid-polimerhibrid $\left(\mathrm{Ag}-\mathrm{TiO}_{2}\right)$ film felszínén lebontható szerves molekulák fotokatalítikus lebontására, amelyen láthatjuk, hogy a besugárzási idő elöre haladásával a szilárd-folyadék határfelületen megkötött szerves molekulák mineralizálódnak. 


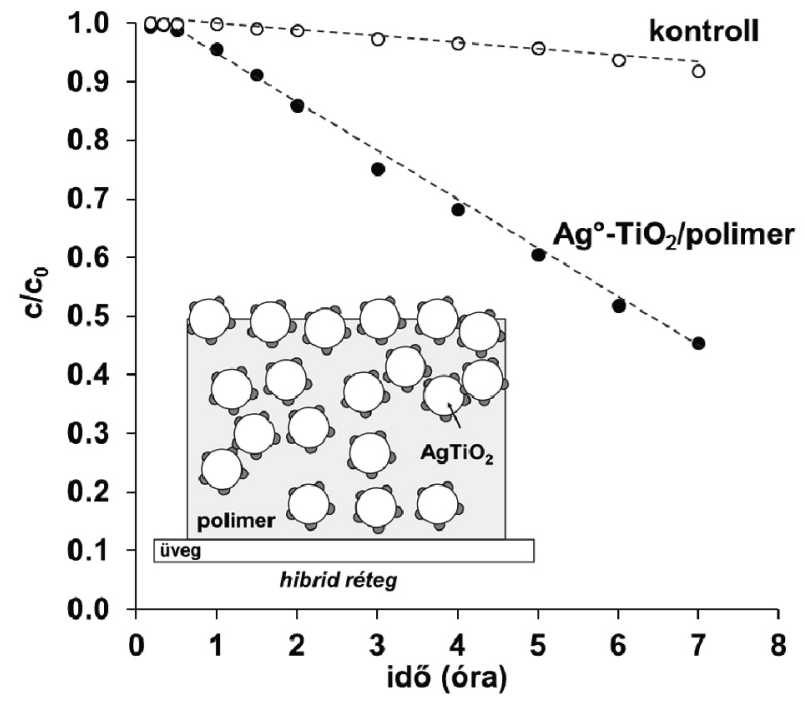

5. ábra. Szerves molekulák fotokatalítikus bontása vizes oldatban $\mathrm{Ag}-\mathrm{TiO}_{2} /$ polimer hibrid fotokatalizátor rétegen.

\section{Environment and Chemistry: Borders and Interfaces}

\section{Introduction}

Looking at our natural environment, it is apparent that there are numerous examples of different surface contact (solid / liquid / gas $)^{1,2}$. Thus, in a first approximation, we investigate a river bank where the water in the basin contains a number of dissolved substances which are in contact with the solid material of the bedrock where the most diverse minerals occur. But this solid surfaces where there is a suitable vegetation typical of the given continent contact with the air and in view of the natural water in the river bed, there are small droplets in the gas phase of the air with high humidity in which different molecules are solved (Fig. 1). Due to the evaporation of the liquid, naturally, at the higher atmospheric heights, the appropriate clouds are formed from which the precipitate is recovered during a condensation process. These clouds are composed of water droplets dispersed in the air which can also be called aerosols (Fig. 2). At the same time, it must be borne in mind that water in the river bed meets with potentially exiting organic liquids, vegetable oils, or hydrocarbon derivatives that can penetrate into the porous structure of the soil and infiltrate the water in the river bed. In this case, however, organic liquid droplets are uniformly dispersed in the aqueous phase forming liquid-liquid interface. In case the environment is contaminated, for example, with detergents, which diffuse into the soil's capillaries; organic liquid droplets may be soluble (solubilized) in the aqueous phase and form micelles ${ }^{2}$. Intake of other organic matter into the living water may lead to the formation of emulsions when there is a sufficient amount of detergent (surfactant) available (Fig. 3). In the light of these processes, it is easy to see that all types of colloidal dispersion systems can easily and spontaneously

\section{Hivatkozások}

1. Ostwald, Wo. Die Welt der vern?chlassigten Dimensionen. Verlag von Steinkopf, Dresden und Leipzig 1916.

2. Buzágh, A. Kolloidika I. II/2 Akadémiai Kiadó. 1946, Budapest.

3. Schay, G. Surface and Colloid Science, Matijevic, E. (ed) Wiley, London 1969, 2, 155.

4. Veres, Á.; Rica, T.; Janovák, L.; Dömök, M.; Buzás, N.; Zöllmer, V.; Seemann, T.; Richardt, A.; Dékány, I. Catal. Today 2012, 181, 156-162.,

https://doi.org/10.1016/j.cattod.2011.05.028

5. Tallósy, S. P. Ph.D. Dissertation, University of Szeged, 2016.

6. Veres, Á.; Ménesi, J.; Juhász, Á., Berkesi, O.; Ábrahám, N.; Bohus, G.; Oszkó, A.; Pótári, G.; Buzás, N.; Janovák, L.; Dékány, I. Colloid Polym. Sci. 2013, 292, 207-217. https://doi.org/10.1007/s00396-013-3063-1

7. Tallósy, S. P.; Janovák, L.; Nagy, E.; Deák, Á.; Juhász, Á.; Csapó, E.; Buzás, N.; Dékány, I. Appl. Surf. Sci. 2016, 371, 139-150., https://doi.org/10.1016/j.apsusc.2016.02.202

8. Tallósy, S. P.; Janovák, L.; Ménesi, J.; Nagy, E.; Juhász, Á.; Dékány, I. J. Adv. Oxid. Technol. 2014, 17, 9-16., https://doi.org/10.1515/jaots-2014-0101

form in our environment (Fig. 2) ${ }^{2,3}$. The interfacial layer formation results molecular interactions between the phases, which means forces the molecules enrichment - because of the field is inhomogeneous and anisotropic- at the boundary layer. The characterization of the resulting adsorption layer (interfacial layer) is possible by the interfacial thermodynamic potential functions quantitatively. It should be noted that the structure and the molecular orientation of the layers are determined by the structure and properties of the interfacial phase (eg. concentration, chemical potential) ${ }^{2,3}$. This means that for the technology to the kinetic stability of the formed disperse systems can be controlled by the interior (bulk) phase properties.

\section{Liquid gas and solid-gas interfaces}

If liquid droplets are dispersed in the air as a gas phase or liquid condensation processes produce saturated water vapour, aerosols are obtained. Of course, the system is further complicated by the fact that airborne dust particles, ranging from nanometers to hundreds of nanometers in size, cause a new interface type, the solid-gas interface. Consequently, it is necessary to calculate with adsorption processes on the surfaces of solid dust particles as well as on soil components (silicates, clay minerals, etc.), which can be quantitatively described in the context of the interfacial physical chemistry. We can calculate the adsorbed amount on the solid material harmful to the environment. From this point of view, it is important to know the parameters of soil-gas interface in advance to use them in environmental technologies, which can result in aerosol binding, air purification and in soil purification. 


\section{Use of environmental technologies to remove impurities}

The environmental technologies are extremely diverse, and in the last century a number of technologies have been developed by chemists and engineers, given that the purity of the environment is fundamental to us. Therefore, we can not discuss the conventional environment purification procedures in this introduction, solely for solid-liquid we would like to present the principle of photocatalytic purification, which is essentially an application of interfacial physical chemistry with the use of solar energy in environmental technologies, for purification technologies applicable to the solid-gas interface. For waste water purification technologies we can use this type of photoreactors as shown in Figure $4^{4,5}$. The essence of photocatalytic operation is that the solid-gas interface and on the solid-liquid interface, the catalysts are operated by the sunlight energy. The oxidation of the pollutants occurred in the adsorption interfacial layer for total mineralization of organic molecules (Fig. 5), which, in the case of hydrocarbon compounds, means the formation of carbon dioxide as the end product ${ }^{6-8}$. 